\title{
WYBORY DO IZBY POSELSKIEJ W 2017 ROKU JAKO WYNIK ZMIAN POLITYCZNYCH W REPUBLICE CZESKIEJ
}

\begin{abstract}
Streszczenie. Wybory do Izby Deputowanych Parlamentu Republiki Czeskiej, które odbyły się w dniach 20 i 21 października 2017 roku, spowodowały najgłębsze zmiany w systemie politycznym w tym kraju. Skład Izby, w porównaniu z poprzednimi wyborami, wyraźnie się zmienił, silne partie osłabły, a sukces odniosły nowe partie. Nowe partie w Izbie nie reprezentują tradycyjnego modelu partii politycznej, nie przynoszą nowych pomysłów i nie wyrastają ze starych systemów ideologicznych. Są partiami populistycznymi, które wykorzystują i wywołują społeczne emocje i oferują proste rozwiązania i są nazywane partiami biznesowo-firmowymi. Autor podkreśla, że zmiany dokonane w 2017 roku, choć bardzo głębokie, są naturalną konsekwencją tendencji widocznych wcześniej, przynajmniej od wyborów w 2010 roku.
\end{abstract}

Słowa kluczowe: czeski system polityczny, czeskie partie polityczne, wybory parlamentarne 2017.

Wybory do Izby Poselskiej przeprowadzone 20 i 21 października 2017 roku były siódmymi wyborami od momentu powstania samodzielnej Republiki Czeskiej. Na rys. 1 zostały przedstawione wyniki wszystkich wyborów. Widać na nim wyraźne zmiany w składzie Izby, naruszające tradycyjną stabilność czeskiego systemu politycznego.

$\mathrm{Z}$ danych zawartych na rys. 1 wypływa wniosek, że aż do roku 2013 w Republice Czeskiej utrzymywał się stabilny system partyjny z wyraźną dominacją dwóch partii politycznych: lewicowej ČSSD (Česká strana sociálně demokratická, Czeska Partia Socjaldemokratyczna) i prawicowej ODS (Občanská demokratická strana, Obywatelska Partia Demokratyczna). Istotną siłą w parlamencie była tradycyjnie partia komunistyczna, KSČM (Komunistická strana Čech a Moravy, Komunistyczna Partia Czech i Moraw), która w czterech kolejnych wyborach zajęła trzecie miejsce pod względem liczby zdobytych mandatów (w 2010 r. czwarte, zachowując jednak liczbę miejsc w Izbie). System ten uzupełniała obecność dwóch (w 1996 r. wyjątkowo trzech) mniejszych partii. Wybory z 2017 roku zepchnęły obie partie lewicowe, ČSSD i KSČM, na odległe pozycje, a ODS zanotowała drugi najgorszy wynik w swojej historii. Mandaty zdobyło aż dziewięć partii, co stworzyło najbardziej rozdrobnioną Izbę od wyborów w 1996 roku, w tym trzy nowe, niemające dotąd swoich przedstawicieli

* Uniwersytet Mikołaja Kopernika w Toruniu, Wydział Politologii i Stosunków Międzynarodowych, Katedra Europy Wschodniej, mcz@umk.pl. 


\section{\begin{tabular}{|l|l|l|l|l|l|}
\hline 199 & 61 & 22 & 18 & 18 & 13
\end{tabular}

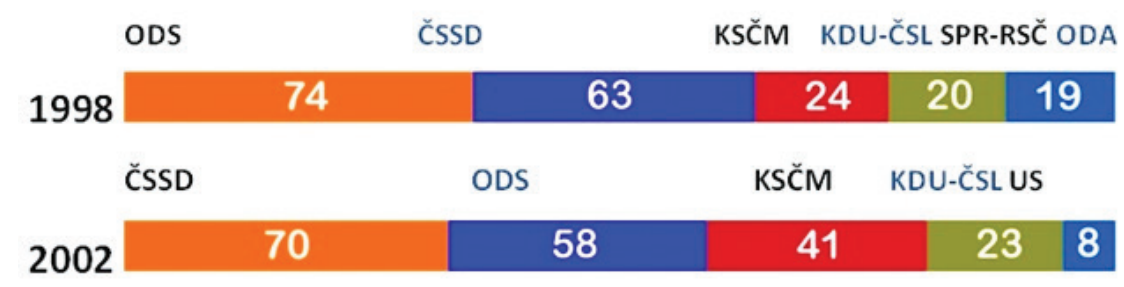

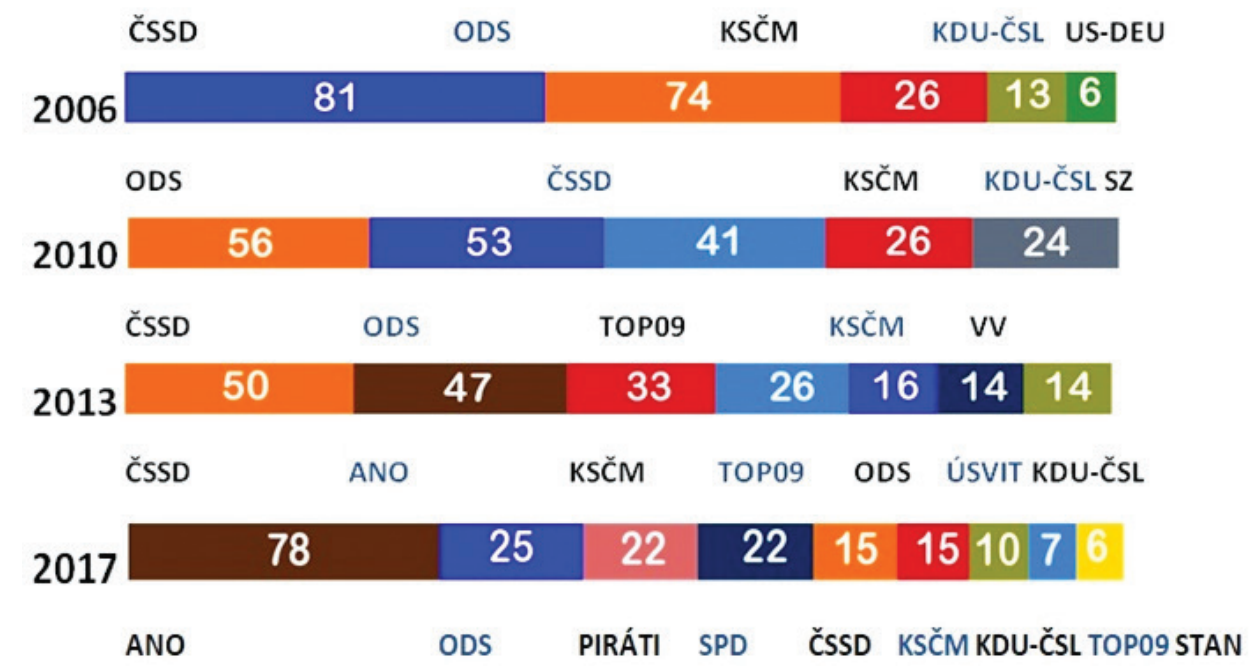

Rys. 1. Wyniki wyborów do Izby Poselskiej Parlamentu Republiki Czeskiej w latach 1996-2017

Źródło: opracowanie własne na podstawie danych Czeskiego Urzędu Statystycznego

(SPD ${ }^{1}$, Piraci i STAN). Niekwestionowanym zwycięzcą wyborów była populistyczna partia ANO założona przez biznesmena słowackiego pochodzenia Andreja Babiša.

Odpowiedź na pytanie o przyczyny destabilizacji czeskiego systemu partyjnego nie jest prosta, tym bardziej, że wśród badaczy nie ma nawet zgody co do tego dlaczego czeski system partyjny był stabilny. Próbujący zbadać to zagadnienie Kevin Deegan-Krause i Tim Haughton musieli przyznać, że trudno znaleźć przekonujące wyjaśnienie instytucjonalne, ekonomiczne czy programowe (Deegan-Krause, Haughton 2010, 227-241). Sean Hanley $(2012,130)$ sugeruje, że stabilność czeskiego systemu partyjnego wynikała z zaufania do wiarygodnych, solidnych, tradycyjnych i skutecznych partii, niezależnie od ich programu. Destabilizacja systemu byłaby więc czymś więcej niż tylko wynikiem rozczarowania

${ }^{1}$ SPD - Svoboda a prrimá demokracie, Wolność i Demokracja Bezpośrednia, jest odnowioną wersją partii Úsvit př́mé demokracie, Świt Demokracji Bezpośredniej, która weszła do Izby w 2013 r. 
działalnością dotychczasowych aktorów sceny politycznej lecz znacznie głębszych zmian społecznych. Mówiąc wprost: system przestał być stabilny bo jego stabilność przestała być postrzegana jako wartość. W tym kontekście można przypomnieć, jak poważnym wstrząsem dla czeskiego społeczeństwa było podpisanie w 1998 roku tzw. umowy opozycyjnej, na podstawie której prawicowa ODS udzieliła poparcia mniejszościowemu rządowi lewicowej ČSSD, formalnie pozostając w opozycji. Duża część społeczeństwa potraktowała ją jako zmowę polityczną dwóch najsilniejszych partii, które, mimo istotnych różnic ideologicznych, zrobią wszystko by utrzymać się u władzy i jako dowód na cynizm polityków. Doświadczenie to mogło wywołać wrażenie, że stabilność polityczna za wszelką cenę nie jest wartością. „Umowa opozycyjna stale wywołuje u wielu ludzi silne emocje [...] Jej ciemny obraz utrwalił się w poglądach większości czeskiego społeczeństwa i mediów głównego nurtu" - pisał jeszcze w 2015 roku Lubomir Kopeček $(2015,11)$. Z drugiej strony jednym z najpopularniejszych czeskich polityków był swego czasu Jan Fischer, bezpartyjny urzędnik, który w 2009 roku stanął na czele tymczasowego rządu i wzmocnił przekonanie, że polityka prowadzona poza istniejącym systemem partyjnym może być lepsza.

Wyniki wyborów z 2017 roku, choć dla systemu partyjnego były prawdziwym trzęsieniem ziemi, są naturalną konsekwencją trendów widocznych podczas analizy wyników wcześniejszych wyborów. Już dwa lata przed wyborami z 2017 roku Vlastimil Havlík (2015b, 204) pisał: „Powstanie nowych partii zaburzyło obraz charakteryzujący czeski system partyjny w przeszłości: zwiększyła się liczba partii relewantnych, wsparcie dla dotychczasowych aktorów sceny politycznej znacząco spadło i pojawiły się nowe warianty koalicji. Ogólnie rzecz biorąc, stabilny niegdyś system partyjny stał się jednym z najbardziej nieprzewidywalnych systemów Europy Środkowo-Wschodniej”. Za przełomowe dla stabilności czeskiego systemu partyjnego uważa się wybory z 2010 roku, w wyniku których po raz pierwszy do Izby Poselskiej weszły aż dwie nowe partie polityczne: TOP09 i VV (Věci veřejné, Sprawy Publiczne). Biorąc pod uwagę poparcie dla wszystkich partii politycznych biorących udział w wyborach, a więc także tych, które nie przekroczyły pięcioprocentowego progu, można stwierdzić, że w 2010 roku aż 38,5\% głosów oddano na partie, które powstały w ciągu poprzednich dwóch lat (Hanley 2012, 120). Tymczasem od roku 1996 poparcie to nigdy nie przekroczyło $11 \%$ (Linek, Lyons 2013, 169). Oceniając tamte wybory J. Chárvat $(2014,152)$ pisał: „Podczas gdy w latach 1998-2009 czeski system partyjny można określić jako mniej lub bardziej uporządkowany i względnie stabilny, z wyraźną tendencją do koncentracji, po 2010 roku zaczął zmieniać się w przeciwnym kierunku. Od wyborów parlamentarnych w 2010 roku można go uznać za stosunkowo niestabilny, głównie ze względu na wysoki poziom zmienności w czeskiej polityce partyjnej i silną tendencję do rozdrabniania".

Wybory z lat 2013 i 2017 nie są jednak pod tym względem prostą kontynuacją wcześniejszych trendów. Należy zwrócić uwagę, że obie nowe partie, które 
zdobyły mandaty w 2010 roku mieściły się w ideologicznych ramach istniejącego systemu. Partia TOP09 powstała w wyniku rozłamu w koalicji KDU-ČSL, a VV, chociaż głosiła konieczność odejścia „dinozaurów polityki”, także trudno uznać za partię antysystemową. Co więcej, VV powstała w 2001 roku, a więc na dziewięć lat przed swoim sukcesem wyborczym, chociaż przez długi czas nie była klasyczną partią polityczną, a lokalnym ruchem miejskim.

Tworzenie się nowych partii politycznych ${ }^{2}$ jest zjawiskiem spotykanym w najbardziej nawet stabilnych systemach politycznych. Szczególnie nie może ono dziwić w systemach, które dopiero się kształtują, nawet jeśli mogą oprzeć się na długiej tradycji demokratycznego życia politycznego. Dynamika sceny politycznej, polegająca nie tyle na rotacji tych samych podmiotów, ale właśnie na nieustanym pojawianiu się nowych, jest charakterystyczne dla większości państw postkomunistycznych w Europie Środkowej i Republika Czeska stanowiła w tym zakresie przypadek szczególny. Warto zwrócić uwagę, że wszystkie nowe partie, które wcześniej czy później odniosły sukces w wyborach były partiami prawicowymi lub centroprawicowymi. S. Hanley, przywołując przykłady DEU (Demokratická unie, Unia Demokratyczna), jej kontynuatorki US-DEU (Unie svobody - Demokratická unie, Unia Wolności-Unia Demokratyczna) i TOP09 podkreśla, że starały się one zaprezentować jako „centroprawicowe partie głównego nurtu oferujące bardziej autentyczne formy konserwatyzmu lub liberalnego konserwatyzmu [...] i mogące skorygować niedociągnięcia istniejących partii w działaniach na rzecz budowy w Republice Czeskiej nowoczesnego społeczeństwa wolnorynkowego w stylu zachodnioeuropejskim" (Hanley 2012, 121-126). Nie oznacza to, że na lewicy nie pojawiały się podobne inicjatywy. Było ich całkiem sporo, zwłaszcza wokół Komunistycznej Partii Czech i Moraw (tworzyli je zarówno działacze niezadowoleni z jej dogmatyzmu, jak i prób zreformowania w kierunku socjaldemokratycznym (zob. Czyżniewski 2017, 45), jednak żadna z nich nie odniosła choćby chwilowego sukcesu.

Nowe partie polityczne, które weszły do Izby Poselskiej w 2013 i 2017 roku to $\mathrm{w}$ większości partie protestu, a nawet, jak Úsvit (SPD), Piraci czy w pewnym sensie ANO, partie antysystemowe (w odniesieniu zarówno do systemu politycznego Republiki Czeskiej, jak i dominującego systemu politycznego w ogóle). Wyjaśnia to w pewien sposób załamanie dotychczasowej pozycji Komunistycznej Partii Czech i Moraw, która odnotowała najgorszy wynik w swojej historii pod względem liczby zdobytych mandatów. Istotnym czynnikiem wpływającym na wysokie poparcie KSČM był dotąd fakt, że stanowiła ona w istocie jedyną partię protestu, którą popierały osoby niezadowolone z sytuacji w kraju, niezależnie

${ }^{2}$ Definicja „nowej partii politycznej” budzi wśród politologów dyskusje, w najbardziej skrajnej formie zakłada ona nie tylko, że nowa partia nie powstała w wyniku rozłamu lub połączenia istniejących partii czy zmiany nazwy i nie uczestniczyła dotąd w wyborach, ale także że wśród jej twórców i przywódców nie ma postaci odgrywających wcześniej znaczącą rolę na scenie politycznej. Zob. Hanley $(2012,121-122)$. 
od poglądów politycznych. Pozycję tę wzmacniało jeszcze to, że komuniści byli zawsze $\mathrm{w}$ opozycji - zgodnie z niepisaną umową partie nie tworzyły z nimi koalicji, mimo że zdobyte przez nią mandaty znacząco ułatwiłyby budowę rządu większościowego. Tymczasem w roku 2017 konkurencja wśród partii protestu istotnie się zwiększyła, umożliwiając oddanie głosu na partię sprzeciwiającą się rzeczywistości społeczno-politycznej, a przy tym nie obciążoną kontekstem ideologicznym.

Niezadowolenie z sytuacji politycznej, gospodarczej i ekonomicznej w państwie jest pierwszym, naturalnym czynnikiem, który bierze się pod uwagę w przypadku zmian w preferencjach wyborczych. Mimo że Republika Czeska jest jednym z najlepiej rozwijających się państw regionu, zapewniającym stały wzrost gospodarczy i coraz lepszy poziom życia, niezadowolenie społeczne ma istotny wpływ na kształt sceny politycznej. L. Linek i P. Lyons, którzy badali zachowania wyborców w latach 1990-2010, wskazali, że wśród wyborców o nieustalonych sympatiach politycznych dużą rolę w podejmowaniu decyzji na kogo głosować odgrywały chwilowe czynniki, np. ocena sytuacji gospodarczej czy zachowania liderów partyjnych (Linek, Lyons 2013, 167). V. Havlík zwraca uwagę, że po wyborach w 2006 roku poziom zadowolenia z sytuacji politycznej i zaufania wyborców do polityki po raz pierwszy spadł poniżej poziomu sprzed wyborów i w zasadzie nigdy go już nie osiągnął. Związane to było z problemami z utworzeniem koalicji, słabością i niestabilnością rządu, konfliktami w koalicji oraz pojawiającymi się oskarżeniami korupcyjnymi (Havlík 2015b, 199). Nastroje społeczne wykorzystywały partie i ruchy polityczne walczące o mandaty w parlamencie, także te, którym trudno zarzucić populizm. W 2010 roku na sprzeciwie wobec korupcji i klientelizmu politycznego swój sukces wyborczy zbudowała partia TOP09. Chociaż wprost nie wskazywano żadnej partii, był to przekaz skierowany przede wszystkim do wyborców ODS. Okazał się skuteczny, bowiem dużą część swojego sukcesu TOP09 zawdzięczała właśnie im (Bureš 2012, 146). Także VV powstała jako wyraz protestu przeciwko rzeczywistości politycznej, chociaż w mniejszej skali, dotyczył on bowiem sytuacji w samorządzie Pragi i jej poszczególnych dzielnic, w których rządzili działacze ODS (tamże, 147). VV przedstawiała się jako ruch społeczny, inicjatywa oddolna niezadowolonych obywateli, co nie do końca odpowiadało prawdzie.

W kolejnych wyborach, które do Izby Poselskiej wprowadziły m.in. populistyczną ANO i antysystemową partię Úsvit, walka z korupcją i zwiększenie przejrzystości życia publicznego, w tym wprowadzenie odpowiednich procedur przy zamówieniach publicznych i wzmocnienie społecznej kontroli sektora publicznego, były już istotną częścią programów zwycięskich partii (Stegmaier, Linek 2014, 388). Badania opinii publicznej przeprowadzone przed wyborami z 2013 roku pokazały znaczący spadek zadowolenia $\mathrm{z}$ istniejącego systemu politycznego. Jako dobry oceniło go zaledwie $10 \%$ badanych, podczas gdy w 2009 roku $22 \%$. Co ciekawe, w lutym 2014 roku, a więc cztery miesiące po wyborach, odsetek ten 
wyniósł już 19\% (Kunštát i in. 2014, 60). Podobny trend pokazują wyniki badań, w których pytano o ocenę bieżącej sytuacji politycznej. W 2013 roku aż 80\% badanych odpowiedziało, że nie jest z niej zadowolonych. W 2009 roku odpowiedzi takiej udzieliło nieco ponad $60 \%$, a w styczniu 2014 roku z sytuacji politycznej w kraju niezadowolona była już tylko połowa badanych (Kunštát i in. 2014, 144). Nastroje społeczne nakazywały już nie tylko wskazywać najistotniejsze problemy, ale krytykować system polityczny jako taki. Nie przypadkowo ANO przystąpiło w 2013 roku do kampanii wyborczej z hasłem „Nie jesteśmy politykami, pracujemy". Powstały dwa lata wcześniej ruch Andreja Babiša jest klasycznym przykładem ugrupowania populistycznego, które swoje działania opiera przede wszystkim na elastycznym dostosowywaniu się do nastrojów i oczekiwań społecznych. Początkowo ANO miało być czymś w rodzaju organizacji pozarządowej działającej na rzecz przyjaznego systemu podatkowego, a sam Babiš zapewniał, że nigdy nie zajmie się polityką. Gdy jednak po kilku występach w mediach, w których krytykował istniejącą sytuację polityczną, spotykał się z coraz większym poparciem obywateli, zaczął poważnie myśleć o wyborach. Im bardziej krytykował rzeczywistość, tym większe zdobywał poparcie, to zaś zachęcało go do zwiększonej krytyki (Tabery 2017, 232-233). W 2017 roku ANO ponownie sięgnęło po tę sprawdzoną retorykę. Dzięki sprawnej kampanii Babišowi udało się stworzyć wizerunek swojego ugrupowania jako alternatywy dla skompromitowanych polityków, czemu nie zaszkodził ani fakt, że przez cztery wcześniejsze lata partia ANO wchodziła w skład koalicji rządowej, a sam Babiš był wicepremierem i ministrem finansów, ani też stawiane mu zarzuty dotyczące nieprawidłowości podatkowych i wyłudzeniu dotacji z UE.

W krytyce systemu politycznego jeszcze dalej posunęło się środowisko skupione wokół innego biznesmena, Tomia Okamury. W 2013 roku wystartował on z powodzeniem do Izby Poselskiej z projektem politycznym pod nazwą Úsvit, a cztery lata później z nowym ruchem, SPD. Okamura przyczynę kryzysu politycznego widzi w samym charakterze systemu, a nie jego elementach. Odrzuca reprezentatywną demokrację parlamentarną z proporcjonalnym systemem głosowania chcąc zastąpienia jej przez demokrację bezpośrednią (Havlík 2015b, 201).

Analiza wyników wyborów w 2017 roku każe zwrócić uwagę na fakt, że największy sukces odniosły partie bez oczywistego oblicza ideologicznego, które trudno nawet umieścić na klasycznej osi lewica - prawica, i nie przedstawiające w swoim programie zwartej wizji zgodnej z którąś z klasycznych ideologii. Jeszcze w 2013 roku na pierwszym i trzecim miejscu znalazły się dwie partie lewicowe o jasnym i konsekwentnym przekazie ideologicznym - socjaldemokraci i komuniści, a na kolejnych dwóch prawicowa ODS i centroprawicowa TOP09, ostatnia nowa partia, która miała jasne oblicze ideologiczne i sprecyzowany, szeroki program polityczny. Tymczasem cztery lata później niekwestionowanym zwycięzcą została bezideowa, populistyczna partia ANO, osiągając drugi najlepszy wynik spośród wszystkich partii od 1996 roku (po ČSSD, która w 2006 roku 
wprowadziła do Izby Poselskiej trzech posłów więcej), a trzecie i czwarte miejsce zajęly równie bezideowe partie Piraci i SPD. Interesujący jest przypadek ODS, która zajęła co prawda drugie miejsce, poprawiając swój fatalny wynik sprzed czterech lat, jednak w kampanii wyborczej porzuciła dotychczasowy wizerunek klasycznej partii konserwatywno-liberalnej na rzecz dość płytkiej retoryki sprzeciwu wobec Unii Europejskiej i przyjmowania uchodźców.

Rozwój czeskiego systemu politycznego już na wczesnym etapie doprowadził do przesunięcia się idei liberalnych (zwłaszcza dotyczących gospodarki) na prawą stronę sceny politycznej, co nie było wcale oczywiste w ówczesnej rzeczywistości państw postkomunistycznych (Kopeček 2001, 244-271). Z kolei po lewej stronie uformował się stabilny, silny blok lewicowy o wyraźnym programie socjalnym i etatystycznym. W wyniku ostatnich wyborów istotną pozycję w Izbie Poselskiej zajęły partie łączące idee liberalne i socjalne, a zarazem trudne do umieszczenia na osi lewica - prawica. Także ten proces widoczny był już podczas wyborów z 2010 roku, zwłaszcza w przypadku partii VV, której strategia marketingowa była kombinacją różnych, często sprzecznych ze sobą elementów retoryki liberalnej, socjalnej i populistycznej. Krytykowano istniejące partie, nazywane dinozaurami, poruszano tematy wywołujące największe zainteresowanie społeczne, takie jak przestępczość, korupcja, wymiar sprawiedliwości, biurokracja, brak przejrzystości zamówień publicznych czy nadużywanie systemu opieki społecznej (Bureš 2012, 148).

Trudności z umieszczeniem na osi lewica - prawica dotyczą przede wszystkim partii ANO i SPD (wcześniej jej poprzedniczki, ÚSVIT), a w dalszej kolejności także Piratów i partii STAN. ANO budowała początkowo swoją pozycję na krytyce systemu neoliberalnego, jednak z czasem sama przesunęła się na pozycje liberalne, koncentrując się na wizerunku swego przywódcy jako odnoszącego sukcesy biznesmena (Stegmaier, Linek 2014, 387). Sam Babiš określił się kiedyś „prawicowcem” a swoją partię „partią prawicową" (Kubát 2015, 85), ale Petr Just i Jakub Chárvat przypuszczają, że stopniowe przesuwanie się ANO na prawo związane jest wyłącznie z profilem jej wyborców, którzy w zdecydowanej większości należeli niegdyś do elektoratu partii prawicowych, w tym ODS, TOP09 i VV, a także z próbą podkreślenia różnicy między ANO a jej lewicowym konkurentem i koalicjantem, ČSSD (Just, Chárvat 2016, 100). Podobny proces przeszły partie Okamury, który początkowo zdecydowanie sprzeciwiał się definiowaniu ich na linii lewica - prawica.

Niezależnie od trudności w ideologicznej charakterystyce partii politycznych widać wyraźnie, że wybory z 2017 roku naruszyły tradycyjną siłę partii lewicowych w parlamencie (zob. rys. 2).

Zwarty, szeroki i konsekwentny program wyborczy został zastąpiony przez zbiór haseł odwołujących się do negatywnych emocji społecznych, wykorzystujących strach i niezadowolenie. W pierwszej kolejności dotyczą one kwestii relokacji uchodźców. Najbardziej skrajne poglądy głosił w tym zakresie Okamura, 
nie tylko ostrzegając $\mathrm{w}$ tym kontekście przed terroryzmem i nadużywaniem przez imigrantów czeskiego systemu socjalnego, ale i zagrożeniem dla europejskich, w tym czeskich, wartości kulturowych i cywilizacyjnych (Okamura nie wahał się przy tym odwoływać do kwestii ochrony chrześcijaństwa mimo znacznego zlaicyzowania czeskiego społeczeństwa) (Havlík 2015a, 133-140). Na rys. 3. przedstawione zostały wyniki badań opinii publicznej dotyczące kwestii budzących największy niepokój ankietowanych. Jak widać, w ciągu pięciu lat istotnie zmniejszyły się obawy o własną sytuację bytową, a zwiększył niepokój związany $\mathrm{z}$ migracją, terroryzmem i światem islamskim.

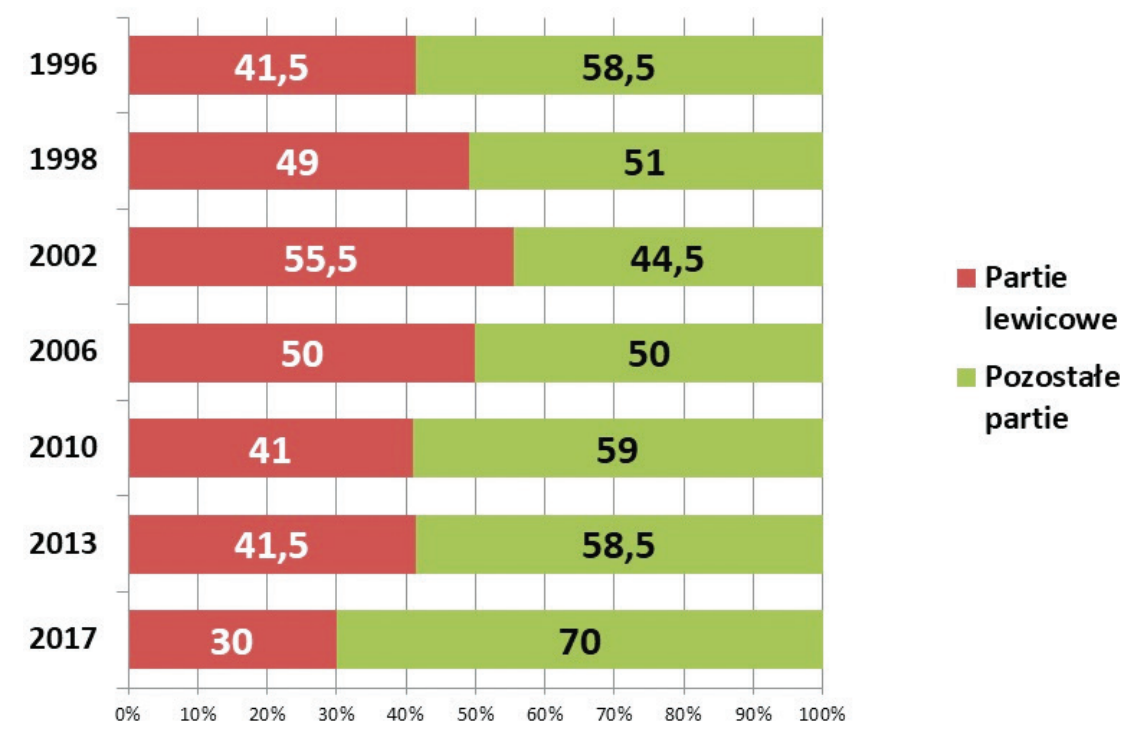

Rys. 2. Udział partii lewicowych w Izbie Poselskiej Parlamentu Republiki Czeskiej w latach 1996-2017 (w \%)

Źródło: opracowanie własne

Podobnie jak w Polsce, polityczny oddźwięk retoryki antyislamskiej i antyuchodźczej nie ma w Republice Czeskiej nic wspólnego z rzeczywistą skalą problemu (pod petycją sprzeciwiającą się unijnym kwotom migracyjnym, przygotowaną przez Blok Przeciwko Islamowi, podpisało się ponad 70 tys. osób) (Havlík 2015a, 142). Jednak świadomość jej użyteczności spowodowała, że stała się ona jednym z głównych motywów kampanii wyborczej w 2017 roku (podobne jak kampanii przed wyborami prezydenckimi, które odbyły się trzy miesiące później, w styczniu 2018 r.), obecnym także w przekazie umiarkowanych, tradycyjnych partii politycznych jak ČSSD i ODS. Już w 2015 roku władze ODS protestowały przeciwko przyjęciu przez Czechy piętnastu rodzin z Syrii, a wiceprzewodnicząca partii, Jana Černochová wzięła udział w demonstracji organizowanej przez stowarzyszenie „Nie chcemy islamu w Republice Czeskiej” (Mocht’ak 2015, 158). 


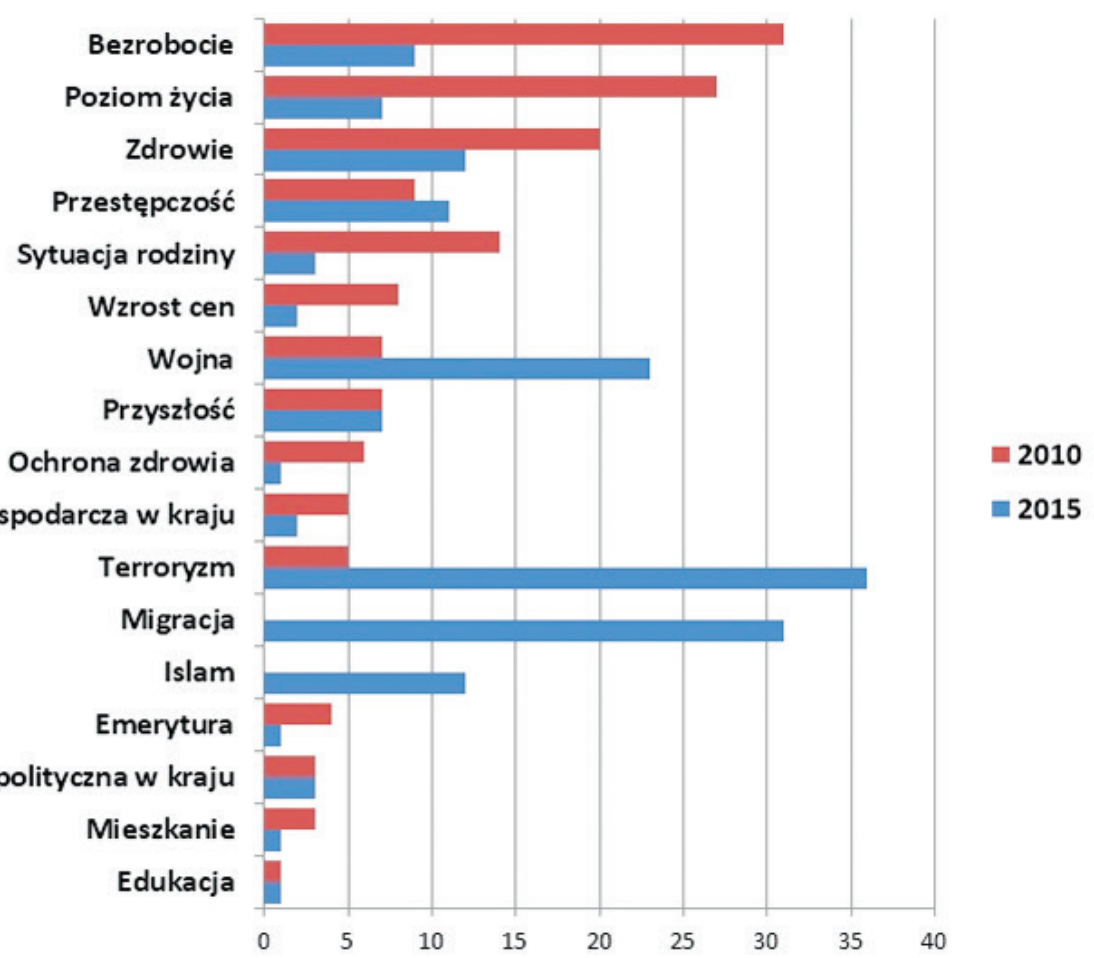

Rys. 3. Wyniki badania opinii publicznej w Republice Czeskiej dotyczącego kwestii budzących największe zaniepokojenie ankietowanych.

Źródło: opracowanie własne na podstawie danych Centrum pro výzkum veřejného mínění, Sociologický stav AV ČR.

Z kolei krótko przed wyborami 2017 roku socjaldemokratyczny premier Bohuslav Sobotka zapowiedział, że Republika Czeska zamiast przyjmowania uchodźców będzie starała się nieść im pomoc w państwach trzecich.

Nowe partie polityczne, które odniosły sukces w wyborach w 2017 roku są odmienne od klasycznego modelu partii nie tylko pod względem braku charakteru ideowego i czytelnej podstawy programowej, ale także pod względem organizacji i struktur. Pod koniec lat 90. XX wieku Jonathan Hopkin and Caterina Paolucci stworzyli nowy model partii politycznej nazwany business firm party i opierający się na porównaniu struktur, metod i celów działania partii z firmą. Just i Charvát podają sześć kryteriów definiujących ten model partii politycznej: ścisły związek z biznesem (założona przez przedsiębiorcę i czerpiąca z jego budżetu), personalizacja partii, niski wskaźnik instytucjonalizacji (łącznie ze zlecaniem szeregu działań podejmowanych przez klasyczną partię podmiotom zewnętrznym), niewielka liczba członków (dla przykładu partia ANO wykazała w chwili rejestracji 732 członków, a w 2015 r. miała ich zaledwie 2715), brak czytelnej ideologii, co pozwala na elastyczne podchodzenie do najważniejszych problemów oparte 
najczęściej na wynikach badań sondażowych, traktowanie wyborcy jako konsumenta ze wszystkimi tego konsekwencjami (Just, Chárvat 2016, 86-87). Pierwszą czeską partią typu biznesowego była VV, która co prawda nie była pierwotnie związana z biznesem, jednak na pewnym etapie rozwoju została przejęta przez struktury korporacyjne i wykorzystana do wzmacniania swoich wpływów w polityce (tamże, 88). Z kolei najbardziej klasycznym przykładem business firm party w warunkach czeskich jest oczywiście ANO.

Raport opisujący geografię wyników wyborczych przeprowadzonych w Republice Czeskiej oceniał kampanię wyborczą z 2013 roku jako „kampanię bez wyrazistych tematów za to z wyrazistymi osobowościami" (Kostelecký i in. 2015, 66). Tę ocenę można by w pełni odnieść także do wyborów z roku 2017. Nowe partie są silnie związane $\mathrm{z}$ osobą lidera, a ich kapitał polityczny w dużym stopniu opiera się na ich popularności. Przed pierwszymi bezpośrednimi wyborami prezydenckimi, w 2013 roku, Tomio Okamura był drugim, po Milošu Zemanie, politykiem w rankingu zaufania społecznego (do wyborów nie stanął tylko dlatego, że Ministerstwo Spraw Wewnętrznych odmówiło rejestracji jego kandydatury z powodu zbyt małej liczby ważnych podpisów na liście poparcia) (Havlík 2015b, 201), rozwój partii VV nabrał dynamiki dopiero wtedy, gdy na jej czele stanął biznesmen Vít Bárta, właściciel największej czeskiej agencji ochrony, a popularność TOP09 w dużym stopniu wynikała z sympatii dla jej współzałożyciela i przewodniczącego Karela Schwarzenberga.

Personalizacja polityki dotyczy w zasadzie jej liderów i związana jest przede wszystkim z ich częstym pojawianiem się w mediach. Nie przekłada się ona na bardziej racjonalne decyzje wyborcze wynikające z lepszego poznania kandydatów, znajomości ich dokonań czy planów. P. Voda i M. Pink przeanalizowali poparcie dla kandydatów startujących z głównych partii do Izby Poselskiej w wyborach w 2006 roku, biorąc pod uwagę ich miejsce zamieszkania oraz przynależność partyjną. Okazało się, że kandydaci poszczególnych partii uzyskiwali podobne poparcie niezależnie od tego, czy mieszkali w obwodzie, w którym kandydowali, czy też nie i bez względu na to, czy są członkami danej partii, czy jedynie ich sympatykami (Voda, Pink 2009, 163-180). Prowadzi to do budowy modelu poparcia wyborczego, w którym popularność lidera, znanego przede wszystkim z mediów, wpływa na poparcie dla partii, to zaś przekłada się na poparcie dla jej kandydatów w terenie, niezależnie od ich rozpoznawalności czy osobistych doświadczeń wyborcy. Taki model nie sprzyja oczywiście racjonalnemu wyborowi, oparty jest na emocjach i zachęca partie do wzmacniania medialnego wizerunku liderów zamiast budowy szerokiej platformy programowej.

Należy w tym miejscu przypomnieć, że czeski system głosowania różni się nieco od systemu polskiego. Co do zasady głosuje się na listy, a nie kandydatów, wrzucając do urny tylko kartę wybranej przez siebie partii ${ }^{3}$. Mandaty zdobyte przez

\footnotetext{
${ }^{3}$ Kartę wrzuca się w zaklejonej kopercie. Wyboru można dokonać już w domu, bowiem karty wszystkich partii przychodzą do wyborcy pocztą. Umieszczenie w kopercie więcej niż jednej karty unieważnia głos.
} 
daną partię dzielone są między kandydatów w porządku ich umieszczenia na liście (jeden zdobyty mandat przypada kandydatowi na pierwszym miejscu, dwa mandaty kandydatom na pierwszym i drugim itd.). Wyborca może jednak uznać, że mandat powinien zdobyć inny kandydat niż ten umieszczony na szczycie listy. System tzw. głosów preferencyjnych pozwala mu wskazać maksymalnie czterech kandydatów z listy, cieszących się jego szczególnym poparciem. Jeśli w skali okręgu zdobędą oni określoną liczbę takich głosów (obecnie to 5\%), mają szansę zdobyć mandat nawet $\mathrm{z}$ odległego miejsca. W 2010 roku zmieniono zasady dotyczące głosów preferencyjnych, zwiększając je z dwóch do czterech. Dzięki tej zmianie do 200-osobowej Izby Poselskiej dostało się aż 46 kandydatów umieszczonych na swoich listach na dalszych miejscach, podczas gdy w 2006 roku tylko sześciu. System głosów preferencyjnych można stosować nie tylko dla zwiększenia szans mniej popularnych kandydatów, ale także dla ich zmniejszenia w przypadku liderów list. Dla przykładu w 2010 roku z samej tylko listy ODS mandatu nie zdobyło 17 kandydatów umieszczonych przez partię na tzw. miejscach biorących (Jurek 2012, 136).

Analizując wyniki kolejnych wyborów do Izby Poselskiej autorzy wskazują na zmiany w liniach podziałów czeskiego społeczeństwa, a co za tym idzie w motywacjach wyborczych. Linia podziałów socjopolitycznych w Czechach nie jest jednoznaczna i od dawna budzi dyskusje. Część badaczy przyjmuje tradycyjnie, że konflikt polityczny w Republice Czeskiej ma charakter konfliktu klasowego, w którym wyborcy głosują na partie broniące ich interesów klasowych. Jednocześnie jednak wskazuje się, że podział klasowy nie tłumaczy w pełni zachowań wyborczych, a decyzje wyborców determinowane są również ich statusem społecznym, materialnym, wiekiem, a nawet wyznaniem, mimo że czeskie społeczeństwo należy do najbardziej zlaicyzowanych w Europie (Bláha, Maškarinec 2014, 714; Linek, Lyons 2013, 165). Wydaje się, że dotychczasowy społeczno-ekonomiczny podział społeczeństwa jest coraz wyraźniej uzupełniany konfliktem definiowanym przez negatywne podejście do polityki, czy jej poszczególnych autorów (Havlík 2015b, 203). Analizując geograficzny rozkład głosów w 2013 roku Petr Bláha i Pavel Maškarinec zauważyli, że ANO uzyskało wysokie poparcie zarówno w regionach o wyższym poziomie bezrobocia jak i wysokim stopniu samozatrudnienia, co wskazuje na zmniejszającą się rolę podziałów opartych na kwestiach socjalno-ekonomicznych (Bláha, Maškarinec 2014, 718).

Wybory z 2017 roku przyniosły najpoważniejszą i najgłębszą zmianę czeskiego systemu politycznego od momentu powstania samodzielnej Republiki Czeskiej ćwierć wieku wcześniej. Odzwierciedla ona zmiany w czeskim społeczeństwie dotyczące motywacji wyborczych, potrzeb politycznych i wartości. Niezależnie od tego, jak istotnie różni się skład Izby Poselskiej wybranej w 2017 roku od poprzednich możemy z całą pewnością stwierdzić, że jest to wynik trendów widocznych już znacznie wcześniej, przynajmniej od wyborów z roku 2010. Oczekiwania i nastroje społeczne, które przyniosły sukces takim partiom jak ANO czy SPD nie są nowym zjawiskiem, lecz obecne były w czeskim życiu politycznym 
już wcześniej i jedynie uległy nasileniu. Destabilizacja czeskiego systemu partyjnego w jego tradycyjnym kształcie oraz sukces partii populistycznych i antysystemowych to nie tylko chwilowy efekt retoryki antyunijnej i antyemigranckiej, czy też znużenia dotychczasowymi partiami. Czeskie wybory z 2017 roku pokazują wyraźnie, że klasyczny model partii politycznej, jako nosiciela dającego się zidentyfikować systemu ideologicznego znacząco się osłabił. Trudno na razie powiedzieć, czy oznacza to, że partie polityczne przestają być postrzegane jako reprezentant interesów konkretnych grup społecznych, czy też po prostu istotnie zmieniły się definicje tych grup. Bez wątpienia jesteśmy świadkami pojawiania się nowych linii podziałów socjopolitycznych bądź zastępujących, bądź uzupełniających dotychczasowe. Nie można nie zwrócić uwagi na istotne zagrożenie, które może być wynikiem tych zmian. Ich beneficjentem, a jednocześnie przyczyną, są partie bezideowe, zbudowane na zasadzie projektu biznesowego, którego celem jest zysk, nie zaś dobro publiczne. Jak ostrzega Erik Tabery: „Jesteśmy świadkami pewnego fenomenu, który nie jest już charakterystyczny wyłącznie dla społeczeństw w trakcie transformacji. Czechy były tu jedynie pionierem. Stary koncept organizowania polityki rozpada się, klasyczne partie tracą członków i siłę perswazji. Ludzie szukają czegoś nowego, co wstrząsnęłoby światem, w którym - jak się wydaje - nie ma wielu alternatyw. Zapewnia to konieczną dynamikę, lecz jednocześnie stać się może lontem, który rozsadzi świat jaki znamy. Dla decydowania politycznego konieczna jest pewna przewidywalność, którą zapewniają prądy ideologiczne" (Tabery 2017, 235).

\section{BIBLIOGRAFIA}

Bláha, Petr, Pavel Maškarinec. 2014. „For whom the Bell Tolls: Grievance Theory and the Rise of New Political Parties in the 2010 and 2013 Czech Parliamentary Elections". Sociológia - Slovak Sociological Review 6: 706-731.

Bureš, Jan. 2012. „Volby 2010 v České republice: fenomén nových stran TOP09 a VV”. Politics in Central Europe 8 (2): 141-151.

Charvát, Jakub. 2014. „The Czech Party System Change since 2010: From Fragile Stability to Stable Fragility”. Revista de Stiinte Politice / Revue des Sciences Politiques 41: 141-154.

Czyżniewski, Marcin. 2014. Zmiana system partyjnego w Republice Czeskiej po wyborach w 2013 roku. Studia Wyborcze 17: 91-110.

Czyżniewski, Marcin 2017. Komunistyczna Partia Czech i Moraw jako element demokratycznego system partyjnego. W Między idealizmem a pragmatyzmem. Wyzwania dla wspótczesnych partii politycznych. Red. Maria Wincławska, Michał Strzelecki. 37-52. Toruń: Wydawnictwo Naukowe Uniwersytetu Mikołaja Kopernika.

Deegan-Krause, Kevin, Tim Haughton. 2010. „A Fragile Stability. The Institutional Roots of Low Party System Volatility in the Czech Republic, 1990-2009”. Politologický Časopis 3: 227-241.

Hanley, Sean. 2012. „Dynamics of new party formation in the Czech Republic 1996-2010: looking for the origins of a "political earthquake"'. East European Politics 28 (2): 119-143.

Havlík Vlastimil. 2015a. Protiislamská politika populistické radikální pravice. W Miroslav Mareš a kol., Ne islámu! Protiislámská politika v České republice. 125-145. Brno: Centrum pro studium demokracie a kultury. 
Havlík, Vlastimil. 2015b. „Stable or not? Patterns of party system dynamics and the rise of the new political parties in the Czech Republic”. Romanian Journal of Political Sciences 1: 185-207.

Jurek, Petr. 2012. „Personalizace volebního systému - př́pad Poslanecké sněmovny Parlamentu ČR”. Politics in Central Europe 8 (2): 124-140.

Just, Petr, Jakub Chárvat. 2016. „Business Firm Parties and the Czech Party System after 2010”. Politics in Central Europe 12 (3): 83-110.

Kopeček, Lubomír. 2015. Deformace demokracie? Opoziční smlouva a česká politika 1998-2002. Brno: Barrister \& Principal.

Kopeček, Michal. 2001 „The Rise and Fall of Czech Post-Dissident Liberalism after 1989”. East European Politics and Societies 25 (2): 244-271.

Kostelecký, Tomáš a kol. Geografie výsledkủ parlamentnich voleb: vzorce volebního chování $v$ Česku. Praha: Academia.

Kubát, Michal. 2015. Przywództwo partyjne w Czechach: pod znakiem gwaltownych przeobrażeń politycznych. W Przywództwo partyjne w państwach postkomunistycznych. Red. Maciej Hartliński. 79-100. Olsztyn: Instytut Nauk Politycznych Uniwersytetu Warmińsko-Mazurskiego.

Kunštát, Daniel a kol. 2014. 25 let české demokracie očima veřejnosti. Praha: Academia.

Linek, Lukáš, Pat Lyons. 2013. Dočasná stabilita? Volebni podpora politických stran v České republice v letech 1990-2010. Praha: Slon.

Mareš, Miroslav a kol. 2015. Ne islámu! Protiislámská politika v České republice. Brno: Centrum pro studium demokracie a kultury.

Mocht’ak, Michal. 2015. Konzervativni protiislamská politika. W Miroslav Mareš a kol., Ne islámu! Protiislámská politika v České republice. 147-164. Brno: Centrum pro studium demokracie a kultury.

Stegmaier, Mary, Lukáš Linek. 2014. „The parliamentary election in the Czech Republic, October 2013". Electoral Studies 35: 385-388.

Tabery, Erik. 2017. Opuštěna společnost. Česká cesta od Masaryka po Babiše. Praha: Paseka.

Voda, Petr, Michal Pink. 2009. „Kandidáti v poslaneckých volbách. Analýza preferenčního hlasování ve volbách do PS PČR v roce 2006”. Středoevropské politické studie 11: 163-180.

\title{
Marcin Czyżniewski
}

\section{ELECTIONS TO THE CHAMBER OF DEPUTIES IN 2017 AS A RESULT OF POLITICAL CHANGES IN THE CZECH REPUBLIC}

\begin{abstract}
Elections to the Chamber of Deputies of the Parliament of the Czech Republic, held on October 20 and 21, 2017, brought about the deepest change in the political system in that country. The composition of the Chamber, in comparison with the previous elections, changed distinctly, the potent parties had weakened and new parties succeeded. The new parties in the Chamber do not represent the traditional model of a political party, they do not bring new ideas and they do not grow out of the old ideological systems. They are populist parties that use and evoke social emotions and offering simple solutions, which are referred to as bussines-firm parties. The author emphasizes that the changes made in 2017, although very deep, are a natural consequence of trends visible earlier, at least since 2010 elections.
\end{abstract}

Keywords: Czech political system, Czech parties, Parliamentary Elections 2017. 